ISSN 1392-3196 / e-ISSN 2335-8947

Zemdirbyste-Agriculture, vol. 101, No. 1 (2014), p. 85-90

DOI 10.13080/z-a.2014.101.012

\title{
Rootstock effect on the performance of sweet cherry (Prunus avium L.) cv. 'Vytẻnų rožinè'
}

\author{
Juozas LANAUSKAS, Darius KVIKLYS, Nobertas USELIS, Pranas VIŠKELIS, \\ Nomeda KVIKLIENĖ, Loreta BUSKIENĖ \\ Institute of Horticulture, Lithuanian Research Centre for Agriculture and Forestry \\ Kauno 30, Babtai, Kaunas district, Lithuania \\ E-mail: j.lanauskas@1sdi.lt
}

\begin{abstract}
In 1999-2009, at the Lithuanian Institute of Horticulture promising clonal rootstocks for sweet cherry (Prunus avium L.) cv. 'Vytėnu rožinė' were evaluated: Ž1 (Prunus cerasus L.), PN ('Vladimirskaya' × 'Polevka' $\times$ Padus mackii (Rupr.) Kom.), P3 and P7 (both - Cerapadus $\times$ (Prunus cerasus L. $\times$ P. avium L.)). Seedlings of a mahaleb cherry (Prunus mahaleb L.) served as a control. The trees on the rootstocks P3 and PN grew like the ones with $P$. mahaleb seedlings. At the end of the experiment their trunk diameter was $18.0-18.4 \mathrm{~cm}$. The trunk diameter of sweet cherry trees on the rootstocks Ž 1 and P7 was smaller -13.8 and $16.1 \mathrm{~cm}$, respectively. The trees on P3 rootstock gave the highest cumulative yield $\left(50.44 \mathrm{~kg} \mathrm{plant}^{-1}\right)$; the trees on $P$. mahaleb seedlings produced the lowest yield $\left(21.17 \mathrm{~kg}\right.$ plant $\left.^{-1}\right)$. The yield on the rest of the rootstocks was similar $-30.26-34.28 \mathrm{~kg} \mathrm{plant}^{-1}$. The highest tree die back was on rootstocks $\check{Z} 1$ and $\mathrm{P} 7$ - correspondingly $44 \%$ and $63 \%$. All the trees survived on $P$. mahaleb seedlings during the experiment. The highest cumulative yield efficiency was recorded on Ž1 and P3 rootstocks $-0.321-0.325 \mathrm{~kg} \mathrm{~cm}^{-2}$ of trunk cross-sectional area. Trees on $P$. mahaleb seedlings were the least yield efficient $-0.119 \mathrm{~kg} \mathrm{~cm}^{-2}$ of trunk cross-sectional area. The smallest fruits were from trees on Ž 1 rootstock -4.7 g. Fruit size on the rest of the rootstocks was significantly higher. Fruits on $P$. mahaleb seedlings had the best taste. Rootstocks P3 and P7 produced numerous suckers. Only slight suckering was recorded for rootstocks PN and $\check{Z} 1$.
\end{abstract}

Key words: Cerapadus, Prunus, root suckers, trunk diameter, yield, yield efficiency.

\section{Introduction}

Seedlings of Prunus mahaleb L. and P. avium L. are the main sweet cherry rootstocks in Lithuania. Vigorous trees on mentioned rootstocks do not satisfy requirements of modern orchards. Furthermore, P. mahaleb performs poorly in heavier soils (Gyeviki et al., 2008) prevalent in a larger part of Lithuania.

Many dwarf and semidwarf sweet cherry rootstocks were released from different breeding programs. MxM, P-HL, Pi-Ku, GM and Weiroot rootstocks are widely used (Callesen, 1998). Most of them are interspecific hybrids from Prunus genus. Rootstocks have different adaptability to soil and climate conditions, they influence fruit tree growth, productivity and fruit quality. Rootstock - scion compatibility may become a problem when genetically distant rootstock is used (Sitarek, Grzyb, 1998; Wertheim, 1998). For the following reasons rootstock tests are continually performed in many countries (Hrotkó, 2008). Some of the recently bred sweet cherry rootstocks were included in tests in Lithuania (Lanauskas, Kviklys, 2006).

Cold hardiness is an important feature for Prunus fruit trees in Lithuania (Duchovskis et al., 2007;
Lanauskas et al., 2012). In the nursery experiments, rootstocks PN, P3 and P7 bred in Russia were selected as cold and disease resistant ( umskis, 1997). The mentioned rootstocks are used in Russia, Ukraine and some other neighbouring countries (Sharco et al., 2000; Upadysheva, 2009; Gryazev, 2011). Distant hybrid Cerapadus was used in their breeding process. Cerapadus is known as a donor of winter hardiness for breeding of cherry rootstocks (Stepanov, 1974; Kolesnikova et al., 1985). Lithuaniabred Ž1 was recognized as a promising rootstock too (Šumskis, 1997). The information about the performance of these rootstocks in the orchard is very limited.

The objective of this trial was to test the effect of rootstocks PN, P3, P7 and Ž1 on growth, yield and fruit quality of sweet cherry cv. 'Vytènų rožinè'.

\section{Materials and methods}

The experiment was carried out in 1999-2009 at the Lithuanian Institute of Horticulture (currently Institute of Horticulture, Lithuanian Research Centre for Agriculture and Forestry) in Babtai, Kaunas district 
(located at $55^{\circ} 60^{\prime} \mathrm{N}, 23^{\circ} 48^{\prime} \mathrm{E}$ ). One-year-old sweet cherry (Prunus avium L.) trees of cv. 'Vytènų rožinè' on clonal rootstocks PN ('Izmaiylovskiy'), P3 ('Moskovija'), P7, Ž1 and mahaleb cherry ( $P$. mahaleb L.) seedlings were planted in the orchard in 1999 and examined for 11 years. P3 and P7 are distant hybrids of Cerapadus $\times$ (Prunus cerasus L. $\times$ P. avium L.) (Yevstratov, 1986) . Cerapadus was produced in Russia by I. V. Michurin in 1935 from a cross of cherry 'Ideal' (Prunus fruticosa Pall. $\times$ P. pensylvanica L.) with the Maack bird cherry (Prunus padus L.) (Blažková, Hlušičková, 2002). PN was originated from 'Vladimirskaya' $\times$ 'Polevka' $\times$ Padus mackii (Rupr.) Kom. Ž1 is selected clone of P. cerasus (Šumskis, 1997). The trees were spaced at $5 \times 3 \mathrm{~m}$ distances. Each graft combination included 16 trees divided into four randomized blocks. Orchard floor management combined frequently mown grass in the alleyways with $1.5 \mathrm{~m}$ wide herbicide strips along tree rows. The soil of the experimental site is EpicalcariEndohypogleyic Cambisol (CMg-n-w-cap), heavy clay loam moderately rich in phosphorus and potassium, containing $2.0-2.2 \%$ of humus, $\mathrm{pH} 7.0-7.2$. Nitrogen fertilizers were applied every spring at a rate of 50-200 g of ammonium nitrate per tree. The orchard was not irrigated.

Climatic conditions in Babtai, Kaunas district are characterized by an average annual temperature of $6.8^{\circ} \mathrm{C}$ and an average annual precipitation of $600 \mathrm{~mm}$, of which $420 \mathrm{~mm}$ occur during the warm period. The lowest winter temperature during the study period was $-23.7^{\circ} \mathrm{C}$. Some years were distinguished for severe spring frosts. In 2002 and 2004, the yield was reduced, in 2005 and 2007 - completely lost.
Trunk diameter $(\mathrm{cm})$ was measured $25 \mathrm{~cm}$ above the graft union each autumn and trunk crosssectional area was calculated. The yield was recorded for the whole experimental plot and expressed as $\mathrm{kg}$ per tree. Yield efficiency index was calculated as a ratio of yield per tree to trunk cross-sectional area and expressed in $\mathrm{kg}$ $\mathrm{cm}^{-2}$. Individual fruit weights were determined on random samples of 100 fruits per plot. The percentage of soluble solids content was measured with a digital refractometer "Atago PAL-3" (Atago Co. Ltd., Japan), total sugars by Bertrand's method, titratable acids (expressed as citric acid) were assessed by titration with a $0.1 \mathrm{~N} \mathrm{NaOH}$ solution (Methods..., 1987). A sample of 50 fruits per plot was used for biochemical analyses. Sensory taste test ( 1 - the lowest score, 5 - the highest one) was done at harvesting by a panel of 9 trained judges. Tree mortality was expressed as the percentage of dead trees at the end of 2009. Rootstock suckering was evaluated on a $0-5$ score scale ( 0 - no suckers, 5 - abundant suckering).

The data were treated by the ANOVA procedure in the $S A S$ statistical program. The differences between treatments were estimated using the Duncan's test $(p<0.05)$.

\section{Results}

During the first three years control trees on Prunus mahaleb seedlings were the least vigorous. From the $4^{\text {th }}$ leaf, the trees on $\check{Z} 1$ were distinguished by the weakest growth. Their trunk diameter at the end of the experiment was the smallest $-13.8 \mathrm{~cm}$. Control trees and trees on rootstocks PN and P3 had the biggest trunk diameter $-18.0-18.4 \mathrm{~cm}$. Trees on P7 showed intermediate growth reaching a trunk diameter of $16.1 \mathrm{~cm}$ (Fig.).

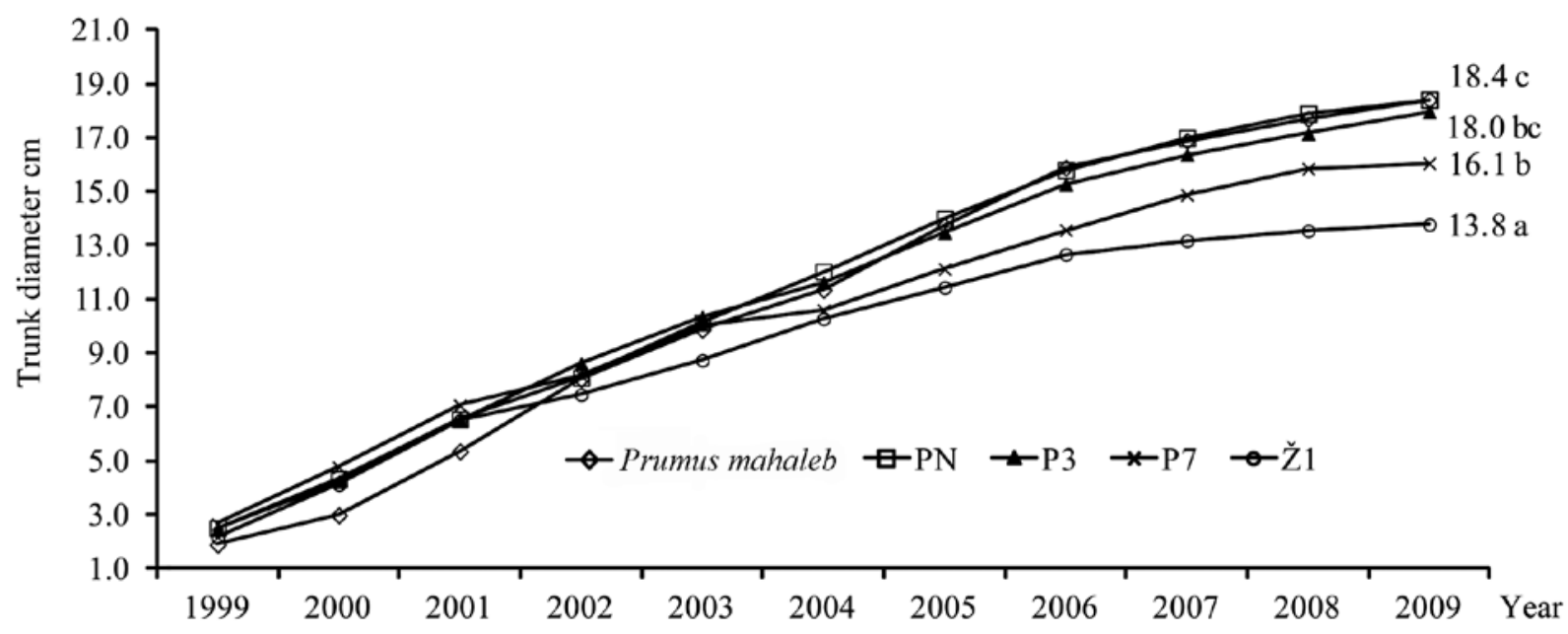

Figure. Trunk diameter of sweet cherry (Prunus avium L.) cultivar 'Vytėnų rožinė'

Sweet cherries started to yield in the $4^{\text {th }}$ leaf. The highest yield was obtained from trees on P3 -1.37 $\mathrm{kg}$ tree $^{-1}$, the lowest - on P. mahaleb seedlings $-0.19 \mathrm{~kg}$ tree $^{-1}$. The trend in cumulative yield was the same. The most productive sweet cherries on $\mathrm{P} 3$ produced 50.44 $\mathrm{kg}$ of fruits plant ${ }^{-1}$, whereas control trees on P. mahaleb seedlings - only $21.17 \mathrm{~kg}$ tree $^{-1}$. Yield on the rest rootstocks was similar $-30.26-30.81 \mathrm{~kg}$ tree $^{-1}$. Generally the yield increased up to the $8^{\text {th }}$ leaf and later declined. Spring frosts strongly influenced the yield. In 2005 and 2007 it was completely destroyed (Table 1).

The highest annual and cumulative yield efficiency was on rootstocks Ž1 and P3. P7 and PN rootstocks were in the second place by the cumulative yield efficiency. Trees on $P$. mahaleb seedlings were the least yield efficient (Table 2). 
Table 1. Yield $\left(\mathrm{kg} \mathrm{tree}^{-1}\right)$ of sweet cherry cultivar 'Vytėnų rožinė'

\begin{tabular}{cccccccc}
\hline Rootstock & 2002 & 2003 & 2004 & 2006 & 2008 & 2009 & Cumulative \\
\hline Prunus mahaleb & $0.19 \mathrm{a}$ & $0.74 \mathrm{a}$ & $2.56 \mathrm{a}$ & $8.66 \mathrm{a}$ & $5.95 \mathrm{a}$ & $3.07 \mathrm{a}$ & $21.17 \mathrm{a}$ \\
PN & $0.65 \mathrm{ab}$ & $1.76 \mathrm{~b}$ & $3.27 \mathrm{ab}$ & $15.38 \mathrm{~b}$ & $6.54 \mathrm{ab}$ & $3.21 \mathrm{a}$ & $30.81 \mathrm{~b}$ \\
P3 & $1.37 \mathrm{c}$ & $3.08 \mathrm{c}$ & $7.51 \mathrm{~b}$ & $23.62 \mathrm{c}$ & $10.00 \mathrm{~b}$ & $4.87 \mathrm{a}$ & $50.44 \mathrm{c}$ \\
P7 & $0.65 \mathrm{ab}$ & $1.68 \mathrm{~b}$ & $2.63 \mathrm{a}$ & $13.89 \mathrm{~b}$ & $7.00 \mathrm{ab}$ & $4.42 \mathrm{a}$ & $30.26 \mathrm{~b}$ \\
Ž1 & $0.88 \mathrm{~b}$ & $2.31 \mathrm{bc}$ & $5.83 \mathrm{~b}$ & $13.24 \mathrm{ab}$ & $9.00 \mathrm{ab}$ & $3.74 \mathrm{a}$ & $34.98 \mathrm{~b}$ \\
\hline
\end{tabular}

Note. Means within each column followed by the same letter do not differ significantly at $P \leq 0.05$.

Table 2. Yield efficiency ( $\mathrm{kg} \mathrm{cm}^{-2}$ of trunk cross-sectional area) of sweet cherry cultivar 'Vytėnų rožinè'

\begin{tabular}{cccccccc}
\hline Rootstock & 2002 & 2003 & 2004 & 2006 & 2008 & 2009 & Cumulative \\
\hline Prunus mahaleb & $0.004 \mathrm{a}$ & $0.010 \mathrm{a}$ & $0.025 \mathrm{a}$ & $0.044 \mathrm{a}$ & $0.024 \mathrm{a}$ & $0.012 \mathrm{a}$ & $0.119 \mathrm{a}$ \\
PN & $0.011 \mathrm{ab}$ & $0.022 \mathrm{a}$ & $0.029 \mathrm{a}$ & $0.079 \mathrm{~b}$ & $0.026 \mathrm{a}$ & $0.012 \mathrm{a}$ & $0.179 \mathrm{~b}$ \\
P3 & $0.024 \mathrm{c}$ & $0.037 \mathrm{~b}$ & $0.072 \mathrm{~b}$ & $0.130 \mathrm{c}$ & $0.043 \mathrm{ab}$ & $0.019 \mathrm{ab}$ & $0.325 \mathrm{c}$ \\
P7 & $0.012 \mathrm{ab}$ & $0.021 \mathrm{a}$ & $0.029 \mathrm{a}$ & $0.096 \mathrm{~b}$ & $0.036 \mathrm{a}$ & $0.022 \mathrm{ab}$ & $0.216 \mathrm{~b}$ \\
Ž1 & $0.020 \mathrm{bc}$ & $0.039 \mathrm{~b}$ & $0.067 \mathrm{~b}$ & $0.100 \mathrm{~b}$ & $0.067 \mathrm{~b}$ & $0.028 \mathrm{~b}$ & $0.321 \mathrm{c}$ \\
\hline
\end{tabular}

Explanation under Table 1

Sweet cherry cultivar 'Vytėnų rožinè' does not bear large fruits. In the experiment, average fruit weight was only about $5.2 \mathrm{~g}$. The biggest fruits were on trees with $P$. mahaleb seedlings $-5.5 \mathrm{~g}$. Fruit weight differed among years: the highest was in 2004, the lowest in 2002 and 2006 (Table 3).

Table 3. Fruit weight (g) of sweet cherry cultivar 'Vytènų rožinė'

\begin{tabular}{cccccccc}
\hline Rootstock & 2002 & 2003 & 2004 & 2006 & 2008 & 2009 & Average \\
\hline Prunus mahaleb & $4.6 \mathrm{c}$ & $5.5 \mathrm{c}$ & $6.6 \mathrm{~b}$ & $4.8 \mathrm{a}$ & $6.1 \mathrm{~b}$ & $5.8 \mathrm{~b}$ & $5.5 \mathrm{~b}$ \\
PN & $4.8 \mathrm{c}$ & $4.9 \mathrm{~b}$ & $6.4 \mathrm{ab}$ & $4.8 \mathrm{a}$ & $5.8 \mathrm{ab}$ & $5.8 \mathrm{~b}$ & $5.4 \mathrm{~b}$ \\
P3 & $4.7 \mathrm{c}$ & $5.2 \mathrm{bc}$ & $6.3 \mathrm{ab}$ & $4.9 \mathrm{a}$ & $5.1 \mathrm{a}$ & $5.6 \mathrm{ab}$ & $5.3 \mathrm{~b}$ \\
P7 & $4.1 \mathrm{~b}$ & $5.0 \mathrm{~b}$ & $6.2 \mathrm{ab}$ & $4.8 \mathrm{a}$ & $5.5 \mathrm{ab}$ & $5.5 \mathrm{ab}$ & $5.2 \mathrm{~b}$ \\
Ž1 & $3.8 \mathrm{a}$ & $4.1 \mathrm{a}$ & $6.0 \mathrm{a}$ & $4.8 \mathrm{a}$ & $5.0 \mathrm{a}$ & $4.9 \mathrm{a}$ & $4.7 \mathrm{a}$ \\
\hline
\end{tabular}

Explanation under Table 1

P3 and P7 rootstocks produced numerous root suckers. Their abundance was scored by 3.8 and 2.1 points, respectively. PN and Ž 1 rootstocks suckered less and $P$. mahaleb seedlings practically did not sucker. All the trees on $P$. mahaleb seedlings survived during the experiment. Good tree persistence was on rootstock P3. The highest tree die back was recorded on the rootstocks Ž1 and P7 - 44\% and 63\%, respectively. Tree survival on $\mathrm{PN}$ rootstock was moderate (Table 4 ).

Table 4. Rootstock suckering ( 0 - no suckers, 5 - abundant suckers) and tree die back, of sweet cherry cultivar 'Vytènų rožinè', 1999-2009

\begin{tabular}{ccc}
\hline Rootstock & $\begin{array}{c}\text { Rootstock } \\
\text { suckering }(0-5 \\
\text { score scale })\end{array}$ & Tree die back \% \\
\hline Prunus & $0.1 \mathrm{a}$ & 0 \\
mahaleb & $1.0 \mathrm{~b}$ & 19 \\
PN & $3.8 \mathrm{~d}$ & 6 \\
P3 & $2.1 \mathrm{c}$ & 63 \\
P7 & $0.9 \mathrm{~b}$ & 44 \\
Ž1 &
\end{tabular}

Explanation under Table 1
Fruit soluble solids content was similar on most of the tested rootstocks. Statistical difference was established only between P3 and Ž1 rootstocks. Fruits on P3 had the lowest soluble solids content, on $\check{Z} 1$ - the highest. Fruit total sugars, titratable acids content and their ratio were similar on all tested rootstocks. Fruits from trees on $P$. mahaleb seedlings were evaluated by the highest taste score. Fruits from trees on P3 rootstock were the least tasty (Table 5).

\section{Discussion}

Economically important are rootstocks, which significantly reduce tree vigour, are physiologically compatible with a number of varieties, improve tree productivity, are cold and disease resistant, well adapt in different soils (Perry, 1987).

In our study, rootstocks P7 and Ž1 reduced trunk diameter by $12-25 \%$ in comparison with Prunus mahaleb seedlings. Such an effect was not very remarkable, but rootstock had positive effect on other important indicators, therefore we could recommend using them in practice. Unfortunately, rootstocks $\mathrm{P} 7$ and Ž1 revealed certain shortages, the main of which is high tree mortality. 
Table 5. Fruit quality and taste ( 1 - the lowest score, 5 - the highest score) of sweet cherry cultivar 'Vytėnų rožinė', 1999-2009

\begin{tabular}{cccccc}
\hline Rootstock & $\begin{array}{c}\text { Soluble solids } \\
\text { content } \%\end{array}$ & $\begin{array}{c}\text { Total sugars } \\
\%\end{array}$ & $\begin{array}{c}\text { Titratable acids } \\
\%\end{array}$ & Sugars:acids & $\begin{array}{c}\text { Taste } \\
(1-5 \text { score scale })\end{array}$ \\
\hline Prunus mahaleb & $16.2 \mathrm{ab}$ & $11.6 \mathrm{a}$ & $0.65 \mathrm{a}$ & $17.8 \mathrm{a}$ & $4.6 \mathrm{c}$ \\
PN & $16.1 \mathrm{ab}$ & $11.4 \mathrm{a}$ & $0.59 \mathrm{a}$ & $19.3 \mathrm{a}$ & $4.2 \mathrm{~b}$ \\
P3 & $15.3 \mathrm{a}$ & $11.0 \mathrm{a}$ & $0.63 \mathrm{a}$ & $17.5 \mathrm{a}$ & $4.0 \mathrm{a}$ \\
P7 & $16.5 \mathrm{ab}$ & $11.5 \mathrm{a}$ & $0.63 \mathrm{a}$ & $18.2 \mathrm{a}$ & $4.3 \mathrm{~b}$ \\
Ž1 & $16.8 \mathrm{~b}$ & $11.1 \mathrm{a}$ & $0.56 \mathrm{a}$ & $19.8 \mathrm{a}$ & $4.2 \mathrm{~b}$ \\
\hline
\end{tabular}

Explanation under Table 1

Fruit trees may die back due to the rootstock and variety physiological incompatibility. Incompatibility problems are frequent when rootstock is distant genetically from the scion (Wertheim, 1998). It is known that rootstock effects sweet cherry mineral nutrition (Usenik et al., 2005; Jiménez et al., 2007). Our observations in the young age showed that trees on rootstocks P7 and Ž1 had serious nutrition disorders (Lanauskas et al., 2007). This may result in severe tree die back after cold winter in 2002 2003. During the experiment all the trees survived on P. mahaleb seedlings and rootstock P3. Due to severe spring frosts, sweet cherries completely lost the yield in 2005 and 2007, and in 2002 and 2004 the yield was lower than expected. The highest sweet cherry yield was on rootstock P3. It more than twice exceeded the yield of control trees on $P$. mahaleb seedlings. The yield on the rest of the tested rootstocks was higher too. Trees on $P$. mahaleb seedlings were the least yield efficient. The rest of the tested rootstocks increased yield efficiency. It was the highest on rootstocks P3 and Ž1. Upadysheva (2009) established good sweet cherry yield efficiency on rootstock PN ('Izmaiylovskiy'). PN was more yield efficient than $P$. mahaleb seedlings in our experiment too.

Low fruit weight in 2006 could be explained by the high yield, whereas in 2002 low rainfall amount and high temperatures in spring could have negative influence. In general, fruit size of 'Vytėnų rožinè' is not large in comparison with worldwide accepted cultivars (Kappel, Lane, 1998). This cultivar is valuable for good cold resistance and productivity. Soluble solids content of 'Vytėnų rožinè' fruits exceeded threshold value recommended by Vangdal (1985) - 14.2\%. Crisosto et al. (2003) indicated consumer-preferable soluble solids content not less than $16 \%$. Only fruits from trees on P3 did not reach that value in our experiment. Most of the tested traits were the best with rootstock P3 but this rootstock produced abundant suckers. Numerous root suckers complicate orchard floor management. Significant suckering was recorded on rootstock P7 too. It has been established that rootstock, derived from Prunus cerasus and $P$. fruticosa species is prone to suckering (FrankenBembenek, Gruppe, 1985; Toribio et al., 1998). Sucker formation of P3 and P7 rootstocks could be inherited from P. padus species. Rootstock Ž1 (Prunus cerasus L.) and PN suckered slightly in our experiment.
Our experiment showed that $P$. mahaleb seedlings were not very good rootstocks for sweet cherry cv. 'Vytėnų rožinė'. P. mahaleb seedlings are usually recommended for cherry orchards grown on light neutral or alkaline soils (Ganji Moghadam, Khalighi, 2006; Gyeviki et al., 2008). In our experiment, the soil was heavy and periodically too wet. Rootstock PN looks promising for higher yield and yield efficiency, but it had no dwarfing effect in our experiment.

\section{Conclusions}

1. Vigour of 'Vytėnų rožinè' sweet cherry (Prunus avium L.) trees grafted on tested rootstocks was in the following range: $\check{Z} 1<\mathrm{P} 7 \leq \mathrm{P} 3 \leq \mathrm{PN}=$ mahaleb cherry ( $P$. mahaleb L.) seedlings. Rootstocks $\mathrm{P} 7$ and $\check{Z} 1$ decreased tree trunk diameter by $12 \%$ and $25 \%$, respectively.

2. The highest cumulative yield was from trees on rootstock P3 $-50.44 \mathrm{~kg}_{\text {tree }}{ }^{-1}$, the least - on P. mahaleb seedlings $-21.17 \mathrm{~kg}$ tree $^{-1}$. Trees on the rest of the rootstocks gave similar yield $-30.26-34.98 \mathrm{~kg}$ tree $^{-1}$.

3. The trees on $P$. mahaleb seedlings had the lowest cumulative yield efficiency index $-0.119 \mathrm{~kg} \mathrm{~cm}^{-2}$ of trunk cross-sectional area (TCSA). The most yield efficient were trees on $\breve{Z} 1$ and $\mathrm{P} 3$ rootstocks -0.321 and $0.325 \mathrm{~kg} \mathrm{~cm}^{-2}$ of TCSA, respectively.

4. Trees on $\check{Z} 1$ rootstock produced the smallest fruits $-4.7 \mathrm{~g}$. Fruits from trees on the rest of the rootstocks were of similar size $-5.2-5.5 \mathrm{~g}$. Fruits on P3 had the lowest soluble solids content, on $\check{Z} 1$ - the highest. Fruits on $P$. mahaleb seedlings had the best taste.

5. All trees survived on P. mahaleb seedlings. The highest tree die back was recorded on rootstocks Ž1 and P7 - correspondingly 44\% and 63\%. Rootstocks P3 and P7 suckered profusely.

\section{Acknowledgements}

This work was carried out within the framework of the long-term research program "Horticulture: agrobiological basics and technologies" implemented by Lithuanian Research Centre for Agriculture and Forestry. 


\section{References}

Blažková J., Hlušičková I. 2002. Testing of wood hardiness to winter freezes in selections from progenies of Cerapadus $\times$ Prunus avium L. crosses. Horticultural Science (Prague), 29: $133-142$

Callesen O. 1998. Recent developments in cherry rootstock research. Acta Horticulturae, 468: 219-228

Crisosto C. H., Crisosto G. M., Metheney P. 2003. Consumer acceptance of 'Brooks' and 'Bing' cherries is mainly dependent on fruit SSC and visual skin color. Postharvest Biology and Technology, 28: 159-167 http://dx.doi.org/10.1016/S0925-5214(02)00173-4

Duchovskis P., Stanys V., Sasnauskas A., Bobinas C. 2007. Cold resistance of Prunus domestica L. and Prunus cerasifera Ehrh. in Lithuania. Acta Horticulturae, 734: 299-303

Franken-Bembenek S., Gruppe W. 1985. Genetic differences in suckering of cherry hybrids (Prunus $\times$ spp.). Acta Horticulturae, 169: 263-268

Ganji Moghadam E., Khalighi A. 2006. Genetic variation of mahaleb (Prunus mahaleb L.) on some Iranian populations using morphological characters. Journal of Applied Sciences, 6: 651-653 http://dx.doi.org/10.3923/jas.2006.651.653

Gryazev V. A. 2011. Nursery. Rostov-on-Don, Russia (in Russian)

Gyeviki M., Bujdosó G., Hrotkó K. 2008. Results of cherry rootstock evaluations in Hungary. International Journal of Horticultural Science, 14 (4): 11-14

Hrotkó K. 2008. Progress in cherry rootstock research. Acta Horticulturae, 795: 171-178

Jiménez S., Pinochet J., Gogorcena Y., Betrán J. A., Moreno M. A. 2007. Influence of different vigour cherry rootstocks on leaves and shoots mineral composition. Scientia Horticulturae, 112: 73-79 http://dx.doi.org/10.1016/j.scienta.2006.12.010

Kappel F., Lane W. D. 1998. Recent sweet cherry introductions from the breeding program at Summerland, British Columbia, Canada. Acta Horticulturae, 468: 105-110

Kolesnikova A. F. Ossipov Y. U. V., Kolesnikov A. I. 1985. New hybrid rootstock for cherries. Acta Horticulturae, 169: $159-162$

Lanauskas J., Kviklys D. 2006. Stone fruit rootstock research in Lithuania. Sodininkyste ir daržininkystè, 25 (4): 170-178

Lanauskas J., Kviklys D., Uselis N. 2007. Evaluation of rootstocks for sweet cherry cv. 'Vytenu Rozine'. Acta Horticulturae, 732: 335-339

Lanauskas J., Uselis N., Kviklys D., Kviklienė N., Buskienė L. 2012. Rootstock effect on the performance of sweet cherry cv. Lapins. Horticultural Science (Prague), 39 (2): 55-60

Methods of plant biochemical investigations. 1987. Ermakov A. I. (ed.)

Perry R. L. 1987. Cherry rootstocks. Rom R. C., Carlson R. F. (eds). Rootstocks for fruit crops, p. 217-264

Sharco L. V., Barabash T. N., Kinash G. A. 2000. Productivity of clonal fruit tree rootstock plantations in Southern steppes of Ukraine. Fruit production on the threshold of $21^{\text {th }}$ century. Minsk, Belarus, p. 112-113 (in Russian)

Sitarek M., Grzyb Z. S. 1998. Bud-take and growth of sweet cherry trees budded on different rootstocks. Journal of Fruit and Ornamental Plant Research, 1: 23-31
Stepanov S. N. 1974. Species and forms of fruit trees and bushes of the USSR and their utilisation in plant breeding: Proceedings of $19^{\text {th }}$ International Horticultural Congress. Warsaw, Poland, 2: 1-12

Šumskis A. 1997. Selection of clone rootstocks for sour and sweet cherries. Sodininkystė ir daržininkystè, 16: 22-29 (in Lithuanian)

Toribio F., Moreno J., Manzano M. A. 1998. Evaluation of rootstocks for cherry trees. Acta Horticulturae, 468: 339-344

Upadysheva G. Y. 2009. Productivity of sweet cherry clonal rootstocks in Moscow region. Sadovodstvo i vinogradarstvo, 4: 45-47 (in Russian)

Usenik V., Štampar F., Šturm K., Fajt N. 2005. Rootstocks affect leaf mineral composition and fruit quality of 'Lapins' sweet cherry. Acta Horticulturae, 667: 247-252

Vangdal E. 1985. Quality criteria for fruit for fresh consumption. Acta Agriculturae Scandinavica, 35 (1): 41-47 http://dx.doi.org/10.1080/00015128509435757

Wertheim S. J. 1998. Rootstock guide: apple, pear, cherry, European plum

Yevstratov A. I. 1986. Cherry and plum (in Russian) 
ISSN 1392-3196 / e-ISSN 2335-8947

Zemdirbyste-Agriculture, vol. 101, No. 1 (2014), p. 85-90

DOI 10.13080/z-a.2014.101.012

\title{
Poskiepių įtaka veislès 'Vytẻnų rožinè' trešnès (Prunus avium L.) produktyvumui
}

\author{
J. Lanauskas, D. Kviklys, N. Uselis, P. Viškelis, N. Kviklienė, L. Buskienė
}

Lietuvos agrarinių ir miškų mokslų centro Sodininkystės ir daržininkystės institutas

\section{Santrauka}

1999-2009 m. Lietuvos sodininkystès ir daržininkystès institute tirti perspektyvūs kloniniai poskiepiai Ž1 (P. cerasus L.), PN ('Vladimirskaya' × 'Polevka' $\times$ Padus mackii (Rupr.) Kom.), P3 ir P7 (abu Cerapadus $\times$ (Prunus cerasus L. $\times$ P. avium L.)) su veislès 'Vytėnu rožinè' trešnėmis. Kontrolinis poskiepis buvo kvapiosios vyšnios (Prunus mahaleb L.) sėjinukai. Trešnès su P3 ir PN poskiepiais augo panašiai kaip įskiepytos i kvapiosios vyšnios sẻjinukus. Tyrimo pabaigoje jų kamienų skersmuo buvo 18,0-18,4 cm. Trešnių su Ž1 ir P7 poskiepiais kamienai buvo iš esmès plonesni - atitinkamai 13,8 ir 16,1 cm. Didžiausias suminis derlius buvo trešniu su P3 poskiepiu $\left(50,44 \mathrm{~kg}_{\text {vaism. }}{ }^{-1}\right)$, mažiausias - kontrolinių vaismedžių, įskiepytų ị kvapiosios vyšnios sẻjinukus $\left(21,7 \mathrm{~kg}\right.$ vaism. $\left.{ }^{-1}\right)$. Vaismedžių su kitais tirtais poskiepiais derlingumas buvo panašus $-30,26-34,28 \mathrm{~kg}$ vaism..$^{-1}$. Per tyrimo laikotarpi išgyveno visi vaismedžiai, i̇skiepyti i kvapiosios vyšnios sejjinukus. Daugiausia trešniu žuvo su poskiepiais Ž1 ir P7 - 44 ir 63 \%. Produktyviausios buvo trešnės su Ž1 ir P3 poskiepiais - 0,321 ir 0,325 $\mathrm{kg} \mathrm{cm}^{-2}$ kamieno skerspjūvio ploto. Mažiausiai produktyvios buvo trešnės, ịskiepytos ị kvapiosios vyšnios sèjinukus $0,119 \mathrm{~kg} \mathrm{~cm}^{-2}$ kamieno skerspjūvio ploto. Smulkiausius vaisius užaugino vaismedžiai su Ž1 poskiepiu - 4,7 g. Kiti poskiepiai padidino vaisių masę. Skaniausias trešnes užaugino vaismedžiai su kvapiosios vyšnios sèkliniais poskiepiais. Poskiepiai P3 ir P7 priaugino daug šaknų atžalų, o poskiepių PN ir Ž1 šaknų atžalų buvo negausu.

Reikšminiai žodžiai: Cerapadus, derlius, kamienų skersmuo, produktyvumas, Prunus, šaknų atžalos. 